\title{
UJI POTENSI PROBIOTIK Lactobacillus plantarium SECARA IN-VITRO
}

\author{
Anik Maunatin', Khanifa ${ }^{2}$ \\ ${ }^{1}$ Jurusan Kimia, Fakultas Sains dan Teknologi, UIN Maulana Malik Ibrahim Malang \\ ${ }^{2}$ Jurusan Biologi Fakultas Sains dan Teknologi UIN Maliki Malang
}

\begin{abstract}
Probiotic is a product containing non-pathogenic microbes live, which was given to animals or humans to fix the rate of growth, efficiency, and increase conversion ration of animal or human health by affecting positively the balance of the gut microbes and microbial pathogen control in the digestive tract. In order to potentially lactic acid bacteria as probiotic candidates must pass the test selection among others such as probiotic test resistance to acid $\mathrm{pH}$, the bile salts, against pathogenic bacteria. This experimental research methods for descriptive use that aim to provide information about the probiotic potential of Lactobacillus plantarum was isolated from the small intestine Mojosari duck (Anas plathyrinchos) with the tests in vitro i.e. the resistance of Lactobacillus plantarum on the condition of the acidic $\mathrm{pH}(2,3$, and 4), bile salt concentration of $0.3 \%(\mathrm{~b} / \mathrm{v})$, inhibition of pathogenic bacteria (Escherichia coli, Staphylococcus aureus and Salmonella typhi) The results showed that on $\mathrm{pH} 2$ the number of cells of bacteria that lives was $4.3 .10^{7} \mathrm{CFU} / \mathrm{ml}$, pH 3 was $3.8 .10^{9} \mathrm{CFU} / \mathrm{ml}$ and $\mathrm{pH} 4$ was 2.7. $10^{10} \mathrm{CFU} / \mathrm{ml}$, the resistance of Lactobacillus plantarum on bile salt showed the number of cells of bacteria that lives was 1.2. $10^{9} \mathrm{CFU} / \mathrm{ml}$. inhibition of the pathogenic bacteria showed that Lactobacillus plantarum could inhibited strong on Escherichia coli and Staphylococcus aureus with diameter of zone was 12.7 $\mathrm{mm}$ and $13.3 \mathrm{~mm}$ but not Salmonella typhi with diameter of zone was $9.3 \mathrm{~mm}$.
\end{abstract}

Key words : probiotic, in vitro, lactobacillus plantarum

\begin{abstract}
ABSTRAK
Probiotik merupakan suatu produk yang mengandung mikroba hidup non-patogen, yang diberikan pada hewan atau manusia untuk memperbaiki laju pertumbuhan, efisiensi konversi ransum, dan meningkatkan kesehatan hewan atau manusia dengan cara mempengaruhi secara positif keseimbangan mikroba usus dan mengendalikan mikroba patogen dalam saluran pencernaan. Penelitian ini mengunakan metode eksperimen secara deskriptif yang bertujuan untuk memberikan informasi tentang potensi probiotik dari Lactobacillus plantarum yang diisolasi dari usus halus itik Mojosari (Anas plathyrinchos) dengan pengujian secara in vitro yaitu ketahanan terhadap kondisi $\mathrm{pH}$ as am $(\mathrm{pH} 2,3$, dan 4), garam empedu dengan konsentrasi 0,3\% (b/v) dan penghambatan terhadap bakteri patogen yaitu Escherichia coli, Staphylococcus aureus dan Salmonella typhi. Hasil penelitian menunjukkan bahwa uji ketahanan Lactobacillus plantarum terhadap pH 2 dengan jumlah sel bakteri yang hidup sebesar 4,3. $10^{7} \mathrm{CFU} / \mathrm{ml}$, pada $\mathrm{pH} 3$ sebesar 3,8.109 $\mathrm{CFU} / \mathrm{ml}$ dan pada $\mathrm{pH} 4$ sebesar $2,7.10^{10}$ CFU/ml. Uji ketahanan Lactobacillus plantarum terhadap garam bile menunjukkan jumlah sel bakteri yang hidup sebesar 1,2. $10^{9} \mathrm{CFU} / \mathrm{ml}$. Uji ketahanan Lactobacillus plantarum terhadap bakteri patogen menunjukkan bahwa Lactobacillus plantarum kuat dalam menghambat Escherichia coli dan Staphylococcus aureus dengan diameter zona hambat yang dibentuk sebesar 12,7 $\mathrm{mm}$ dan 13,3 mm namun sedang dalam menghambat Salmonella typhi dengan diameter zona hambat sebes ar $9,3 \mathrm{~mm}$.
\end{abstract}

Kata kunci : probiotik, in vitro, lactobacillus plantarum

\section{PENDAHULUAN}

Kebutuhan masyarakat terhadap protein hewani mengalami peningkatan seiring dengan bertambahnya jumlah penduduk dari tahun ke tahun. Hasil penelitian Setiawan (2006), menunjukkan bahwa, rata-rata laju konsumsi protein antara tahun 1999 - 2004 sebesar 3,34\% pertahun dan laju kebutuhan protein sebesar $0,20 \%$ pertahun. Berkenaan dengan hal tersebut, maka produktivitas ternak khususnya unggas perlu ditingkatkan untuk memenuhi kebutuhan masyarakat akan protein hewani.

Abun (2008), yang menyatakan bahwa probiotik dalam penerapannya 
sebagai produk bioteknologi terdiri atas tiga jenis produk yaitu probiotik yang mengandung kultur bakteri, kultur khamir, dan kultur molds (kapang) serta kombinasinya. Di dalam bidang peternakan, arti probiotik cukup penting karena saat ini peternak percaya bahwa makanan berlemak tinggi seperti dalam produk pakan ternak banyak mengandung kolesterol. Probiotik yang terdapat dalam saluran pencernan mampu menetralisir toksin yang dihasilkan bakteri patogen, menghambat pertumbuhan bakteri patogen dengan mencegah kolonisasinya di dinding usus halus, mempengaruhi aktivitas enzim di usus halus, asimilasi kolesterol dan meningkatkan pertumbuhan serta performan ternak.

Berdasarkan dari berbagai hasil penelitian, Bakteri Asam Laktat (BAL) memiliki banyak manfaat bagi kehidupan tidak hanya pada manusia namun pada kehidupan hewan ternak. Beberapa spesies BAL setelah diteliti mempunyai potensi sebagai probiotik. Menurut Khuzaemah (2005), probiotik merupakan pakan imbuhan berupa mikroorganisme yang dapat hidup di saluran pencernaan, bersimbiosis dengan mikroorganisme yang ada, bersifat menguntungkan, dapat meningkatkan pertumbuhan dan efisiensi pakan tanpa mengalami proses penyerapan. Probiotik menyeimbangkan populasi mikrobia pada saluran pencernaan, mengendalikan mikroorganisme patogen pada tubuh inang dan lingkungan, dan menstimulasi imunitas inang. Gildberg et al. (1997), menyatakan bahwa dalam saluran pencernaan tumbuh normal dalam jalur intestin suatu bakteri asam laktat yang memberikan efek positif yang penting terhadap kesehatan tubuh, yaitu melalui kemampuannya menekan pertumbuhan bakteri patogen intestin penyebab diare, serta menstimulasi sistem kekebalan tubuh (imun). Keseimbangan mikroorganisme dalam saluran pencernaan harus tetap terjaga yaitu antara bakteri patogen dan non-patogen, karena jika terjaga akan memberikan efek positif terhadap kesehatan tubuh. Adanya keseimbangan yang terjaga akan memberikan dampak yang bernilai positif, sesuai dengan firman Allah SWT dalam surat al-Mulk ayat 3 - 4 yang berbunyi:

"Yang Telah menciptakan tujuh langit berlapis-lapis. kamu sekali-kali tidak melihat pada ciptaan Tuhan yang Maha Pemurah sesuatu yang tidak seimbang. Maka Lihatlah berulang-ulang, Adakah kamu lihat sesuatu yang tidak seimbang? Kemudian pandanglah sekali lagi niscaya penglihatanmu akan kembali kepadamu dengan tidak menemukan sesuatu cacat dan penglihatanmu itupun dalam keadaan payah" (QS. al-Mulk 67: 3-4).

Khuzaemah (2005), menyatakan bahwa level serat kasar yang tinggi dalam ransum sering menyebabkan kecernaan menurun dan pemanfaatan nutrien ransum menjadi menurun serta penurunan bobot badan. Guna mengatasi penurunan kecernaan dan penurunan bobot badan akibat penggunaan serat kasar yang tinggi dalam ransum maka penelitian ini melakukan pengujian potensi probiotik L.plantarum hasil isolasi dari usus halus itik Mojosari (Anas plathyrichos) secara in vitro yang nantinya akan dimanfaatkan untuk pembuatan pakan itik probiotik.

\section{METODE PENELITIAN}

Bahan-bahan yang digunakan antara lain biakan murni Lactobacillus plantarum yang diisolasi dari usus halus itik Mojosari (Anas plathyrinchos), MRSA (deManRogosa-Sharpe Agar) dan MRSB (deManRogosa- Sharpe Broth) (Merck), NA (Nutrient Agar) dan NB (Nutrient Broth)(Merck), Oxgall (Merck) 0,3\% (b/v), Escherichia coli, Staphylococcus aureus, Salmonella typhi, Lactobacillus paracasei, alkohol 70\%, etanol (Merck), $\mathrm{NaOH}$ (Merck), $\mathrm{HCl}$, aquadest, kapas dan spritus.

Metode penelitian yang digunakan adalah metode eksperimen dengan penulisan secara deskriptif untuk memberikan informasi untuk memberikan informasi tentang potensi probiotik dari $L$. plantarum yang diisolasi dari usus halus 
pertumbuhan kebanyakan spesies bakteri adalah 4 dan 9. Pengaruh $\mathrm{pH}$ terhadap pertumbuhan bakteri ini berkaitan dengan aktivitas enzim. Enzim dibutuhkan oleh bakteri untuk mengkatalis reaksi-reaksi yang berhubungan dengan pertumbuhan bakteri. Apabila $\mathrm{pH}$ dalam suatu medium atau lingkungan tidak optimal, maka akan mengganggu kerja enzim-enzim tersebut, yang pada akhirnya akan mempengaruhi pertumbuhan bakteri itu sendiri (Pelczar dan Chan, 1986).

Kondisi keasaman lambung berfungsi sebagai pintu gerbang pertama untuk melakukan seleksi bakteri sebelum masuk ke usus. Toleransi terhadap $\mathrm{pH}$ asam merupakan salah satu syarat penting suatu BAL untuk dapat menjadi probiotik. Hal tersebut disebabkan bila L.plantarum masuk ke dalam saluran pencernaan hewan ternak unggas, maka L.plantarum harus mampu bertahan dari $\mathrm{pH}$ asam lambung dan perut yang mempunyai $\mathrm{pH}$ sangat rendah antara 2-4.

Saat kondisi puasa (kosong tanpa adanya makanan), pH lambung berkisar antara 1,0 - 2,0 (Wahyudi dan Samsundari, 2008). Pernyataan tersebut ditunjang oleh Mallory et al. (1973), ketahanan terhadap asam lambung, berkaitan dengan sifat probiotik yang penting untuk bertahan hidup di dalam lambung. Supaya probiotik dapat bekerja secara efektif, perlu seleksi strain yang mampu bertahan pada kondisi asam. Penelitian ini menguji Lactobacillus plantarum yang diisolasi dari usus halus itik petelur Mojosari mampu hidup dalam usus yang mengandung konsentrasi garam empedu $0,3 \%$ (b/v) dengan lama inkubasi 24 jam. Ketahanan Lactobacillus plantarum terhadap garam empedu merupakan syarat penting untuk probiotik seperti halnya ketahanan terhadap asam. Konsentrasi garam empedu $0,3 \%$ merupakan konsentrasi yang kritikal nilai yang cukup tinggi untuk menyeleksi galur yang resisten terhadap garam empedu (Gilliland et al., 1984). Penelitian ini menggunakan konsentrasi garam empedu $0,3 \% \quad(\mathrm{~b} / \mathrm{v})$. Uji ketahanan L.plantarum terhadap asam dalam penelitian ini dilakukan pada $\mathrm{pH}$ 2, 3, dan 4. Hasil uji ketahanan L.plantarum terhadap asam disajikan dalam Tabel 1.

Tabel 1. Ketahanan L.plantarum Terhadap Asam

\begin{tabular}{|c|c|}
\hline $\mathrm{pH}$ & $\begin{array}{c}\text { Rerata jumlah sel bakteri } \\
(\mathrm{CFU} / \mathrm{ml})\end{array}$ \\
\hline 2 & $4,3 \cdot 10^{\prime}$ \\
\hline 3 & $3,8 \cdot 10^{9}$ \\
\hline 4 & $2,7.10^{10}$ \\
\hline
\end{tabular}

Tabel 1 menunjukkan bahwa semakin besar nilai $\mathrm{pH}$ media maka jumlah bakteri asam laktat yang hidup semakin meningkat. Adapun jumlah inokulum awal yang ditambahkan pada jam ke nol adalah $10^{9} \mathrm{CFU} / \mathrm{ml}$. menurut Raccach et al., (1979) dalam Rostini (2007), starter bakteri asam laktat yang digunakan untuk uji probiotik sebanyak $10^{8}$ sampai $10^{9} \mathrm{CFU} / \mathrm{ml}$.

Menurut Kimoto et al. (1999) paparan pada kondisi yang sangat asam dapat mengakibatkan kerusakan membran dan lepasnya komponen intraseluler hilangnya komponen-komponen intraseluler seperti $\mathrm{Mg}, \mathrm{K}$ dan lemak dari sel, yang mampu menyebabkan kematian bakteri yang tidak tahan asam. Sedangkan bakteri tahan asam memiliki ketahanan yang lebih besar terhadap kerusakan membran akibat terjadinya penurunan $\mathrm{pH}$ ekstraseluler dibandingkan dengan bakteri yang tidak tahan terhadap asam. Menurut Bender dan Marquis (1987), ketahanan Lactobacilli pada $\mathrm{pH}$ rendah terjadi karena (1) kemampuannya dalam mempertahankan $\mathrm{pH}$ internal lebih alkali dari pada $\mathrm{pH}$ eksternal, (2) mempunyai membran sel yang lebih tahan terhadap kebocoran sel akibat terpapar $\mathrm{pH}$ rendah

Hasil pengamatan menunjukkan bahwa pada $\mathrm{pH} 2$ jumlah sel bakteri L.plantarum yang hidup mengalami penurunan $2 \log$ (penurunan sebesar $10^{2}$ ), pada $\mathrm{pH} 3$ tidak mengalami penurunan dari jumlah sel bakteri yang hidup dan pada $\mathrm{pH}$ 4 jumlah sel bakteri L.plantarum yang 
hidup mengalami kenaikan sebesar 1 log $\left(10^{1}\right)$. Menurut Triyana dan Nurhidayati (2007), dalam keadaan asam Lactobacillus mampu mempertahankan kadar keasaman sitoplasmanya sehingga protein dan enzim yang berada di dalam sel tetap dapat bekerja secara optimal. Karakter inilah yang menyebabkan Lactobacillus sangat ideal sebagai probiotik saluran pencernaan.

Berdasarkan hasil pengujian ketahanan terhadap $\mathrm{pH}$ asam menunjukkan bahwa L.plantarum yang diisolasi dari usus halus itik Mojosari berpotensi sebagai kandidat probiotik karena mampu tumbuh pada kisaran $\mathrm{pH}$ asam dan sesuai dengan pernyataan Kimoto et al. (1999), bakteri probiotik akan mempunyai efek pada lingkungan usus apabila jumlah populasi dari bakteri tersebut mencapai minimal $10^{6}$ $10^{8} \mathrm{CFU} / \mathrm{ml}$.

\subsection{Ketahanan L.plantarum Terhadap Garam Bile}

Menurut Ganong (1983), garam empedu merupakan garam natrium seperti taurochlorate dan glycholate yang berfungsi dalam emulsi lemak menjadi misel sehingga mudah diserap oleh mukosa usus. Beberapa jenis BAL mampu bertahan pada konsentrasi garam empedu yang lebih tinggi dari $0,3 \%$. Garam empedu mulai disekresi dari $\mathrm{pH} 4$ karena pada $\mathrm{pH}$ tersebut mulai terjadi pencernaan lemak di duodenum dengan enzim lipase yang diemulsikan dengan garam empedu dan lesitin. Cairan empedu merupakan campuran dari asam empedu, kolesterol, asam lemak, fosfolipid dan pigmen empedu. Sekresi pankreas juga mengandung serangkaian enzim pencernaan. Kombinasi tersebut bersifat bakterisidal bagi mikroorganisme dalam tubuh manusia dan hewan kecuali beberapa genus penghuni usus yang tahan terhadap garam empedu. Ketahanan terhadap garam empedu merupakan prasyarat suatu isolat BAL untuk dapat membentuk koloni dan melakukan aktivitas metabolisme pada inang (Havenaar et al., 1992).
Usus halus dan kolon mengandung konsentrasi asam empedu yang relatif tinggi dan dapat menghambat pertumbuhan atau bahkan membunuh sebagian besar bakteri. Bakteri asam laktat yang akan diuji potensi probiotik harus mampu tumbuh pada $0,3 \%$ - $0,5 \%$ agar bile (Wahyudi dan Samsundari, 2008). Ketahanan L.plantarum terhadap garam empedu merupakan syarat penting untuk probiotik seperti halnya ketahanan terhadap asam. Konsentrasi garam empedu $0,3 \%$ merupakan konsentrasi yang kritikal nilai yang cukup tinggi untuk menyeleksi galur yang resisten terhadap garam empedu (Gilliland et al., 1984). Penelitian ini menguji Lactobacillus plantarum yang diisolasi dari usus halus itik petelur Mojosari mampu hidup dalam usus yang mengandung konsentrasi garam empedu $0,3 \%$ (b/v) dengan lama inkubasi 24 jam. Ketahanan Lactobacillus plantarum terhadap garam empedu merupakan syarat penting untuk probiotik seperti halnya ketahanan terhadap asam. Konsentrasi garam empedu $0,3 \%$ merupakan konsentrasi yang kritikal nilai yang cukup tinggi untuk menyeleksi galur yang resisten terhadap garam empedu (Gilliland et al., 1984). Penelitian ini menggunakan konsentrasi garam empedu $0,3 \%(\mathrm{~b} / \mathrm{v})$.

Tabel 2. Ketahanan L.plantarum Terhadap Garam Bile

\begin{tabular}{|l|l|}
\hline Perlakuan & $\begin{array}{l}\text { Rerata jumlah sel } \\
\text { bakteri (CFU/ml) }\end{array}$ \\
\hline Garam Bile 0,3\% (b/v) & $1,2.10^{9}$ \\
\hline Tanpa Garam Bile & $1,4.10^{9}$ \\
\hline
\end{tabular}

Tabel 2 menunjukkan jumlah bakteri yang hidup pada media dengan penambahan oxgall $0,3 \%(\mathrm{~b} / \mathrm{v})$ sebesar 1,2 . $10^{9} \mathrm{CFU} / \mathrm{ml}$ dan mengalami kenaikan $1 \mathrm{log}$ karena jumlah inokulum awal yang ditambahkan pada jam ke nol adalah $10^{8}$ CFU/ml. Jumlah Lactobacillus plantarum yang hidup pada garam empedu $0,3 \%$ (b/v) setelah inkubasi 24 jam hampir sama dengan jumlah sel bakteri yang hidup pada 
MRS broth sebagai kontrol yaitu 1,4. 10 CFU/ml.

Menurut Bezkorovainy (2006), halangan yang paling serius bagi ketahanan probiotik pada usus halus adalah garam empedu. Studi resistensi probiotik pada garam empedu secara in vitro dapat dibagi menjadi dua tipe yaitu studi ketahanan dan pertumbuhan. Studi ketahanan pada Lactobacillus dan Bifidobacterium dengan konsentrasi $0-1,5 \%$ selama kurang dari 3 jam, karena Lactobacillus kebanyakan lebih tahan dari pada Bifidobacterium, konsentrasi yang digunakan untuk Lactobacillus lebih tinggi sekitar 0,3\% Oxgall. Menurut Du Toit et al. (1999), ketahanan bakteri asam laktat terhadap garam empedu berkaitan dengan enzim bile salt hidrolase (BSH) yang membantu menghidrolisa garam empedu terkonjugasi, sehingga mengurangi efek racun bagi sel. Adanya toleransi terhadap garam empedu tersebut diduga disebabkan oleh peranan polisakarida sebagai salah satu komponen penyusun dinding sel bakteri gram positif (Astuti dan Rahmawati, 2010). Karena sel bakteri L.plantarum pada penelitian ini mampu tumbuh dalam garam bile sehingga bakteri tersebut berpotensi sebagai kandidat probiotik.

\subsection{Penghambatan L. plantarum Terhadap Bakteri Patogen}

Beberapa senyawa yang dihasilkan oleh BAL yang bersifat antimikroba diantaranya adalah asam-asam organik, hidrogen peroksida dan senyawa protein atau komplek protein spesifik yang disebut bakteriosin. Kemampuan mikroba probiotik bakteri asam laktat untuk menekan pertumbuhan bakteri patogen disebabkan karena kemampuannya untuk memproduksi senyawa antimikroba seperti asam laktat dan asam asetat, hidrogen peroksida yang cukup besar dan bakteriosin. Akumulasi senyawa tersebut di dalam sel terjadi karena bakteri asam laktat tidak menghasilkan enzim katalase. (Salminen dan Wright, 1993).
Salah satu kriteria yang harus dimiliki oleh BAL yang berpotensi sebagai probiotik adalah kemampuannya untuk menghambat bakteri patogen dan mampu berkompetisi dengan bakteri patogen untuk mempertahankan keseimbangan mikroflora usus (Gildberg, 1997). Pengujian ini menggunakan 3 jenis bakteri patogen, yaitu Escherichia coli, Staphylococcus aureus, dan Salmonella typhi. Ketiga bakteri patogen tersebut sering kita ketahui sebagai bakteri yang sering menginfeksi timbulnya penyakit yang menyerang saluran pencernaan baik pada manusia maupun pada hewan. Hasil uji penghambatan Lactobacillus plantarum terhadap ketiga bakteri patogen dapat dilihat pada Gambar 1 dan Tabel 3.

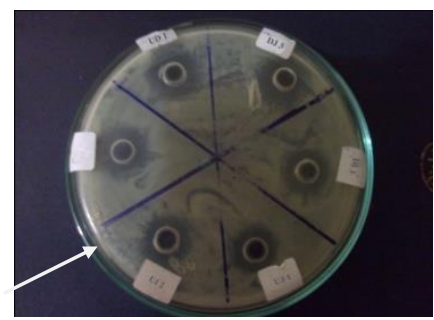

(a)

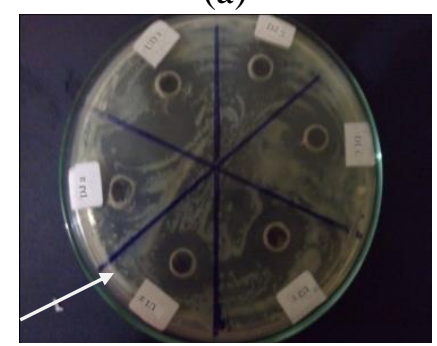

(b)

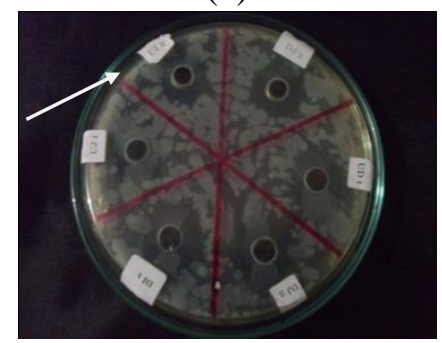

(c)

Gambar 1. Penghambatan L.plantarum terhadap (a) Escherichia coli (b) Staphylococcus aureus dan Salmonella typhi (c) 
Tabel 3. Penghambatan L.plantarum Terhadap Bakteri Patogen

\begin{tabular}{|c|c|}
\hline Bakteri patogen & $\begin{array}{l}\text { Rerata diameter } \\
\text { zona hambat }(\mathrm{mm})\end{array}$ \\
\hline Escherichia coli & 12,7 \\
\hline Staphylococcus aureus & 13,3 \\
\hline Salmonella typhi & 9,3 \\
\hline
\end{tabular}

Tabel 3 menunjukkan zona penghambatan L.plantarum terhadap Escherichia coli adalah 12,7 $\mathrm{mm}$, Staphylococcus aureus sebesar 13,3 mm dan Salmonella typhi sebesar 9,3 $\mathrm{mm}$. Menurut Davis dan Stout (1971) dalam Dewi (2010), bahwa penentuan kekuatan daya suatu antibakteri adalah jika daerah hambatan $20 \mathrm{~mm}$ atau lebih berarti sangat kuat, daerah hambatan $10-20 \mathrm{~mm}$ berarti kuat, daerah hambatan $5-10 \mathrm{~mm}$ berarti sedang dan daerah dengan hambatan $5 \mathrm{~mm}$ atau kurang berarti lemah. Segingga aktivitas antibakteri yang dibentuk oleh L.plantarum terhadap bakteri Escherichia coli adalah kuat, terhadap bakteri Staphylococcus aureus adalah kuat dan terhadap bakteri Salmonella typhi adalah sedang. Jumlah sel bakteri patogen yang dipakai untuk Escherichia coli $10^{10}$ CFU/ml, untuk Staphylococcus aureus dan Salmonella typhi adalah $10^{9} \mathrm{CFU} / \mathrm{ml}$, sedangkan jumlah sel L.plantarum adalah $10^{10} \mathrm{CFU} / \mathrm{ml}$.

Menurut McKane dan Kandel (1985), bakteri Gram positif (Staphylococcus aureus) memiliki satu lapisan tebal peptidoglikan, dan asam teikoat sedangkan bakteri Gram negatif (Escherichia coli dan Salmonella typhi) terdiri dari tiga lapisan peptidoglikan. Sensitivitas suatu bakteri terhadap substrat antimikroba dipengaruhi oleh lapisan peptidoglikan yang menyusun dinding sel. Lapisan peptidoglikan pada bakteri Gram negatif lebih tipis dibandingkan dengan bakteri Gram positif. Peptidoglikan bakteri Gram negatif hanya $1 \%$ hingga $2 \%$ dari berat kering sel sedangkan bakteri Gram positif mencapai $20 \%$ dari berat kering sel. Membran luar dari Gram negatif tersusun atas lipoprotein $30 \%$, fosfolipid $20-25 \%$, protein $40-45 \%$ yang berfungsi sebagai pertahanan terhadap lingkungan luar terhadap aksi antibiotik sehingga penisilin lebih sulit untuk mencapai target kerja.

Pratiwi (2008), menyatakan bahwa dinding sel bakteri Gram negatif tidak mengandung asam teikoat (berbeda dengan Gram positif yang memiliki 2 asam teikoat yaitu asam lipoteikoat dan asam teikoat dinding) dan karena hanya mengandung sejumlah kecil peptidoglikan, maka dinding sel bakteri Gram negatif relatif lebih tahan terhadap kerusakan mekanis. Sehingga dari hasil pengamatan menunjukkkan bahwa Staphylococcus aureus (Gram positif) lebih mudah dihambat oleh aktivitas antibakteri Lactobacillus plantarum daripada Escherichia coli dan Salmonella typhi (Gram negatif)

Hasil penelitian ini menunjukkan bahwa L.plantarum efektif dalam menghambat pertumbuhan bakteri pathogen yang sering kita ketahui dapat menimbulkan infeksi pada saluran pencernaan baik pada manusia atau hewan, L.plantarum yang paling efektif menghambat adalah pada bakteri Staphylococcus aureus kemudian Escherichia coli. sesuai dengan kriteria besarnya daya hambat, maka L.plantarum lebih kuat dalam menghambat bakteri Gram positif (Staphylococcus aureus) dan bakteri Gram negatif (Escherichia coli). Berdasarkan kemampuan menghambat bakteri patogen tersebut maka L.plantarum berpotensi sebagai kandidat probiotik.

\section{KESIMPULAN}

1. Ketahanan L.plantarum terhadap asam menunjukkan rata-rata jumlah sel bakteri yang hidup pada $\mathrm{pH} 2$ sebesar 4,3. $10^{7} \mathrm{CFU} / \mathrm{ml}, \mathrm{pH} 3$ sebesar 3,8.109 CFU/ml, dan $\mathrm{pH} 4$ sebesar 2,7. $10^{10}$ $\mathrm{CFU} / \mathrm{ml}$.

2. Ketahanan L.plantarum terhadap garam bile $0,3 \% \quad(b / v)$ menunjukkan bahwa jumlah sel bakteri yang tumbuh adalah 1,2. $10^{9} \mathrm{CFU} / \mathrm{ml}$. 
3. Penghambatan L.plantarum terhadap bakteri patogen menunjukkan bahwa L.plantarum kuat dalam menghambat Escherichia coli dan Staphylococcus aureus dengan rata-rata diameter penghambatan terhadap Escherichia coli sebesar 12,7 mm, Staphylococcus aureus sebesar 13,3 mm, dan sedang menghambat Salmonella typhi dengan rata-rata diameter zona hambat sebesar 9,3 mm.

\section{SARAN}

Penelitian selanjutnya untuk lebih mengetahui potensi L.plantarum sebagai probiotik adalah pengujian secara in vivo yaitu kemampuan menempel pada sel epitel usus halus saluran pencernaan itik dan pengujian dengan hewan coba agar aplikasi L.plantarum dalam produk probiotik lebih optimal.

\section{DAFTAR PUSTAKA}

Astuti, dan A. Rahmawati. 2010. Asimilasi Kolesterol dan Dekonjugasi Garam Empedu oleh Bakteri Asam Laktat (BAL) dari Limbah Kotoran Ayam Secara In Vitro. Prosiding Seminar Nasional Penelitian, Pendidikan dan Penerapan MIPA. Jurusan Pendidikan Pendidikan Biologi FMIPA UNY.

Bezkorovainy, A. 2006. Probiotics: Determinants of Survival and Growth in The Gut. American J. Of Clin. Nut. 72(2): 399 - 405.

Dewi, Fajar Kusuma. 2010. Aktivitas Antibakteri Ekstrak Etanol Buah Mengkudu (Morinda citrifolia L.) Terhadap Bakteri Pembusuk Daging Segar. Surakarta: Skripsi Jurusan Biologi Fakultas Matematika dan Ilmu Pengetahuan Alam. Universitas Sebelas Maret.

Dewi, Fajar Kusuma. 2010. Aktivitas Antibakteri Ekstrak Etanol Buah
Mengkudu (Morinda citrifolia L.) Terhadap Bakteri Pembusuk Daging Segar. Surakarta: Skripsi Jurusan Biologi Fakultas Matematika dan Ilmu Pengetahuan Alam. Universitas Sebelas Maret.

Gildberg, A. Mikkelsen, Sandaker, E. and Ring, E. 1997. Probiotic Effect of Lactid Acid Bacteria in The Feed on Growth and Survival of Fry of Atlantic Cod (Gadus morhua) Hydrobiologia. Appl, Microbiology. 352: 279-285.

Gilliland SE, TE Staley and LJ Bush. 1984. Importance of Bile Tolerance of Lactobacillus acidophilus Used as A Dietary Adjunct. J. Dairy Science 67: 3045-3051.

Harimurti, Sri. Endang Sutriswati, Nasroedin, dan Kurniasih. 2007. Bakteri Asam Laktat dari Intestin Ayam Sebagai Agensia Probiotik. Animal Production. Vol. 9. No. 2. Hal. 82-91. ISSN 1411-2027.

Khuzaemah, S. 2005. Pengaruh Aras Serat Kasar Ransum terhadap Kecernaan Serat kasar, Protein kasar dan Energi Metabolis pada Itik Tegal Jantan. Semarang: Skripsi Fakultas Peternakan Universitas Diponegoro.

Kimoto H, J Kurisaki, N.M Tsuji, S Ohmomo and T Okamoto. 1999. Lactococci as Probiotic Strains: Adhesion to Human Enterocyte-like Caco-2 Cells and Tolerance to Low $\mathrm{pH}$ and Bile. Lett. In Appl. Microbiol. Vol. 29: 313-316.

McKane, L. and J. Kandel. 1985. Microbiology: Essential and Application. New York: McGrawHill Book Company.

Pratiwi, Sylvia T. 2008. Mikrobiologi Farmasi. Jakarta: Erlangga.

Rostini, Iis. 2007. Peranan Bakteri Asam Laktat (Lactobacillus plantarum) Terhadap Masa Simpan Filet Nila Merah pada Suhu Rendah. Bandung: Makalah Fakultas Perikanan dan Ilmu Kelautan. Universitas Padjadjaran. 
Salminen, S., Ouwehand, A., Benno, Y. \& Lee Y.K. 1999. Probiotics: How Should Be Defined? Trends in Food Science and Technology. Vol.10: $107-110$.

Schillinger U, and Lucke F. 1989. Antbacterial activity of Lactobacillus sake isolated from meat. Appl Environ Microbiol. 55: 1901 - 1906.

Setiawan, N. 2006. Perkembangan Konsumsi Protein Hewani di Indonesia (Analisis Hasil Susenas 1999-2004). Pengkajian. Tidak diterbitkan. Padjadjaran: Fakultas Peternakan Univ Padjadjaran.
Setiawan, N. 2006. Perkembangan Konsumsi Protein Hewani di Indonesia (Analisis Hasil Susenas 1999-2004). Pengkajian. Tidak diterbitkan. Padjadjaran: Fakultas Peternakan Univ Padjadjaran.

Wahyudi, Ahmad dan Sri Samsundari. 2008. Bugar Dengan Susu Fermentasi. Rahasia Hidup Sehat Panjang Umur. Malang: UMM Press.

Zavaglia AG, Kociubinski G, Perez P, Antoni GD. 1998. Isolation and Characterization of Bifidobacterium Strains of Probiotik formulation. $J$. Food Protect. 61(7) 865-873. 